\title{
Jacek Jaworski
}

Wyższa Szkoła Bankowa w Gdańsku

e-mail: jjaworski@wsb.gda.pl

ORCID: 0000-0002-6629-3497

\section{Renata Gmińska}

Wyższa Szkoła Bankowa w Gdańsku

e-mail: gminscy@poczta.onet.pl

ORCID: 0000-0002-0780-0428

\section{WIZERUNEK GLÓWNEGO KSIĘGOWEGO W OPINII STUDENTÓW WYŻSZEJ SZKOLY BANKOWEJ W GDAŃSKU}

\section{IMAGE OF CHIEF ACCOUNTANT IN THE OPINION OF STUDENTS OF WSB UNIVERSITY IN GDAŃSK}

DOI: $10.15611 / p n .2019 .11 .16$

JEL Classification: A13, M12, M41

Streszczenie: Celem badania było ustalenie cech zawodowych i osobistych głównego księgowego przez przyszłych finansistów. Badanie wykonano wśród studentów Wyższej Szkoły Bankowej w Gdańsku z wykorzystaniem kwestionariusza ankietowego. Główny księgowy okazuje się zawodem rozpoznawanym przez połowę respondentów. W ich opinii główny księgowy to osoba odpowiedzialna, dokładna, uczciwa i dochowująca terminów, mająca duże doświadczenie w rachunkowości, dbająca o procedury, potrafiąca dochować tajemnicy i dobrze zorganizowana. Relatywnie nisko oceniono jego umiejętność kierowania ludźmi, pracy w zespole i komunikatywność. Główny księgowy rzadko jest postrzegany jako osoba życzliwa i łatwo nawiązująca kontakty. Jego pracę uznano za pozytywnie wpływającą na inne komórki organizacyjne. Według badanych jest to zawód z przyszłością, mający wysoką rangę wśród profesji związanych z rachunkowością. Jest jednak rzadko wskazywany jako ten, który chcieliby wykonywać studenci.

Słowa kluczowe: główny księgowy, wizerunek zawodu, cechy zawodowe i osobiste, etyka.

Summary: The aim of the study was to determine the professional and personal components of the chief accountant in the opinion of future financiers. The survey was conducted among students of the WSB University in Gdańsk using. The chief accountant turns out to be a profession recognized by half of the respondents. In their opinion, the chief accountant is a responsible, accurate, honest and timely person, with extensive experience in accounting, caring for procedures, able to keep secrets and well organized. His ability to manage people, team work and communication skills were rated relatively low. The chief accountant is rarely seen 
as a kind and easy-going person. His work was considered to have a positive impact on other organizational units. According to the respondents, this is a profession with a future, having a high rank among the professions related to accounting. However, it is rarely indicated as the one that students would like to do.

Keywords: chief accountant, image of the profession, professional and personal characteristics, ethics.

\section{Wstęp}

Wśród wielu zawodów związanych z rachunkowością na pierwszy plan wysuwa się profesja głównego księgowego. Z racji funkcji i obowiązków jest to zawód o szczególnym znaczeniu dla istnienia i funkcjonowania większości organizacji, w szczególności prowadzących księgi według zasad opisanych Ustawą z dnia 24 września 1994 r. o rachunkowości.

$\mathrm{W}$ polskim prawie nie ma regulacji dotyczących wymagań w zawodzie księgowego $^{1}$. Z racji zajmowanej pozycji w strukturach organizacji oczekuje się jednak, żeby była to osoba nie tylko doskonale znająca zagadnienia rachunkowości i prawa podatkowego, ale również odznaczająca się wieloma dodatkowymi umiejętnościami, charakteryzująca się odpowiedzialnością, kreatywnością, mająca szerokie horyzonty myślowe, patrząca w przyszłość, odznaczająca się wysoką etyką. W tym kontekście ciekawym zagadnieniem staje się pytanie o postrzeganie zawodu głównego księgowego przez osoby rozpoczynające karierę zawodową.

W literaturze przedmiotu pojęcie wizerunku jest różnie ujmowane. K. Wójcik [1997, s. 41] definiuje wizerunek jako wyobrażenie o samych sobie, natomiast E. Pluta [2001, s. 32] - jako zbiór obranych technik komunikacyjnych, powstający jako efekt zamierzonych i niezamierzonych decyzji. Wśród różnych rodzajów wizerunku występuje również wizerunek zawodowy, czyli ogół podzielanych przez ludzi przekonań, poglądów i opinii na temat określonej grupy zawodowej (szerzej: [Czaplińska, 2015, s. 14-17]). O wizerunku zawodowym człowieka decydują zarówno kwalifikacje i doświadczenia zawodowe, jak i zachowania, prezentowane postawy, styl życia, umiejętności budowania i utrzymywania relacji interpersonalnych.

Celem badania było określenie podstawowych cech zawodowych i osobistych składających się na wizerunek głównego księgowego w opinii przyszłych księgowych i finansistów. Badanie przeprowadzono wśród studentów Wyższej Szkoły Bankowej w Gdańsku z wykorzystaniem kwestionariusza ankietowego. Uzyskane wyniki poddano analizie ilościowej.

${ }^{1}$ Wyjątek stanowi zawód głównego księgowego w sektorze finansów publicznych - wymagania dotyczące tej profesji zawiera Ustawa z dnia 27 sierpnia 2009 r. o finansach publicznych (UoFP). 


\section{Zadania i oczekiwane cechy glównego księgowego. Przegląd literatury}

Profesja głównego księgowego jest zawodem zaufania publicznego. Jego rola w jednostce gospodarczej jest obecnie niezwykle istotna ze względu na zadania, które wykonuje. Przeważnie zajmuje on pozycję na najwyższych szczeblach struktury organizacyjnej. Zgodnie z Rozporządzeniem Ministra Pracy i Polityki Społecznej z dnia 7 sierpnia 2014 roku w sprawie klasyfikacji zawodów i specjalności na potrzeby rynku pracy oraz zakresu jej stosowania [Rozporządzenie Ministra Pracy i Polityki Społecznej z dnia 7 sierpnia 2014 r. ...] zawód głównego księgowego znajduje się w grupie wielkiej 1 - Przedstawiciele władz publicznych, wyżsi urzędnicy i kierownicy. Miejsce głównego księgowego w tej klasyfikacji przedstawia tabela 1.

Tabela 1. Miejsce głównego księgowego w klasyfikacji zawodów i specjalności

\begin{tabular}{|l|l|}
\hline Grupa zawodowa & Nazwa grupy zawodowej i zawodu/specjalności \\
\hline Wielka & 1 - przedstawiciele władz publicznych, wyżsi urzędnicy i kierownicy \\
\hline Duża & 12 - kierownicy do spraw zarządzania i handlu \\
\hline Średnia & 121 - kierownicy do spraw obsługi biznesu i zarządzania \\
\hline Elementarna & 1211 - kierownicy do spraw finansowych \\
\hline Zawód/specjalność & $\mathbf{1 2 1 1 0 1}$ - glówny księgowy \\
\hline
\end{tabular}

Źródło: opracowanie na podstawie [Rozporządzenie Ministra Pracy i Polityki Społecznej z dnia 7 sierpnia 2014 r. ...].

Opis zawodu, zadania oraz wykaz kompetencji zawodowych głównego księgowego zawiera Krajowy Standard Kompetencji Zawodowych (KSKZ) [Krajowy Standard... 2013]. Według tego dokumentu główny księgowy zajmuje się planowaniem, koordynowaniem i nadzorowaniem prowadzenia rachunkowości organizacji.

Do jego zadań należą:

- planowanie, analizowanie i kontrolowanie sytuacji finansowej jednostki,

- kierowanie pracami działów finansowo-księgowych,

- monitorowanie prawidłowości rozliczeń finansowych z organami podatkowymi, ZUS, instytucjami finansowymi i kontrahentami,

- opracowywanie sprawozdań finansowych i raportów na potrzeby organizacji i instytucji zewnętrznych (m.in. US, ZUS, GUS, banki),

- nadzorowanie prawidłowego obiegu dokumentów finansowych i ich archiwizowania.

Zadania głównego księgowego ustawowo zostały uregulowane jedynie wobec pracowników sektora publicznego. W pozostałych jednostkach to kierownik określa oczekiwania wobec osoby zajmującej to stanowisko. Formułując te wymagania, można skorzystać z wymagań opisanych w art. 54 UoFP, uzupełniając je o wymaga- 
nia ustalone w rozdziale 8a UoR dotyczące uprawnień do usługowego prowadzenia ksiąg rachunkowych. Głównym księgowym może być zatem osoba, która:

1) ma obywatelstwo państwa członkowskiego Unii Europejskiej, Konfederacji Szwajcarskiej lub państwa członkowskiego Europejskiego Porozumienia o Wolnym Handlu (EFTA) - strony umowy o Europejskim Obszarze Gospodarczym, chyba że odrębne ustawy uzależniają zatrudnienie w jednostce sektora finansów publicznych od posiadania obywatelstwa polskiego;

2) ma pełną zdolność do czynności prawnych oraz korzysta z pełni praw publicznych;

3) nie była prawomocnie skazana za przestępstwo przeciwko mieniu, przeciwko obrotowi gospodarczemu, przeciwko działalności instytucji państwowych oraz samorządu terytorialnego, przeciwko wiarygodności dokumentów lub za przestępstwo skarbowe;

4) posiada znajomość języka polskiego w mowie i piśmie w zakresie koniecznym do wykonywania obowiązków głównego księgowego;

5) spełnia jeden z poniższych warunków:

a) ukończyła ekonomiczne jednolite studia magisterskie, ekonomiczne wyższe studia zawodowe, uzupełniające ekonomiczne studia magisterskie lub ekonomiczne studia podyplomowe i posiada co najmniej 3-letnią praktykę w księgowości,

b) ukończyła średnią, policealną lub pomaturalną szkołę ekonomiczną i ma co najmniej 6-letnią praktykę w księgowości,

c) jest wpisana do rejestru biegłych rewidentów na podstawie odrębnych przepisów,

d) ma certyfikat księgowy uprawniający do usługowego prowadzenia ksiąg rachunkowych albo świadectwo kwalifikacyjne uprawniające do usługowego prowadzenia ksiąg rachunkowych, wydane na podstawie odrębnych przepisów.

Uogólniając, można stwierdzić, że osoba ubiegająca się o stanowisko głównego księgowego powinna mieć wyższe wykształcenie ekonomiczne, najlepiej o profilu rachunkowość lub finanse. Kandydat na to stanowisko powinien wykazać się także doświadczeniem w pracy w finansach i rachunkowości, w tym kilkuletnim doświadczeniem na stanowisku kierowniczym. Dobrze, aby posiadał branżowe uprawnienia i licencje, a także polskie lub międzynarodowe kwalifikacje zawodowe z dziedziny finansów. Bardzo ważna jest również biegła znajomość oprogramowania finansowo-księgowego, a przede wszystkim przepisów (m.in. prawa bilansowego i podatkowego). Oczekiwane (wymagane) kompetencje zawodowe głównego księgowego wydają się zatem dość dobrze opisane. Potwierdzają to liczne publikacje naukowe, do których należą m.in. opracowania Z. Lutego [2007] czy M. Rogus [2013].

Jak wskazują inne badania, to nie tylko wiedza i doświadczenie merytoryczne są uważane za istotne kompetencje zawodowe charakteryzujące tę grupę zawodową. Wielu autorów (m.in. [Robles 2012; Klaus 2010; Mitchell i in. 2010; Smółka 2008; Nealy 2005]) w swoich opracowaniach dowodzi, że bardzo ważne są także kompetencje miękkie. Drugi z przywołanych autorów wykazał na przykład, że 75\% 
długoterminowego sukcesu w pracy zależy od umiejętności ludzi, a tylko $25 \%$ - od wiedzy technicznej. Inne badania wskazują, że twarde umiejętności tylko w 15\% przyczyniają się do sukcesu, podczas gdy $85 \%$ sukcesu wynika z posiadania umiejętności miękkich [Watts, Watts 2008] (cytowane w [John 2009]). Podobnie jest w zawodach związanych z rachunkowością. Globalizacja, złożoność biznesu, a także zmiany technologiczne spowodowały, że księgowi muszą wykazać się nie tylko odpowiednią wiedzą i umiejętnościami technicznymi, ale przede wszystkim - kompetencjami miękkim, w tym zdolnością komunikowania się, koordynowania, pracy pod presją i rozwiązywania problemów [Ramlall, Ramlall 2014; Low i in. 2013; Paszkiewicz, Silska-Gembka 2013].

Główny księgowy, aby wykonać stawiane przed nim zadania, powinien odznaczać się również określonymi umiejętnościami miękkimi. Należą do nich kompetencje interpersonalne obejmujące skuteczną komunikację, umiejętność słuchania i negocjowania, zdolność do pracy zespołowej, umiejętność rozwiązywania konfliktów [Kabalski 2015, s. 158-159], a także samodzielność, odpowiedzialność i rzetelność w wykonywaniu swoich obowiązków. Poza tym powinien mieć cechy przywódcze i zdolności kierowania ludźmi [Ramlall, Ramlall 2014, s. 651].

Praca głównego księgowego wiąże się z dużym stresem będącym wynikiem ponoszonej odpowiedzialności, dlatego też od osób wykonujących ten zawód wymaga się odporności na stres i umiejętności radzenia sobie z nim [Brzeska 2018, s. 133-136]. Częste zmiany w regulacjach międzynarodowych i krajowych, a także wprowadzanie wartości szacunkowych w rachunkowości powodują, że główny księgowy musi być kreatywny, umieć analitycznie myśleć [Mohamed, Lashine 2003, s. 6], stale podnosić swoje umiejętności i wzbogacać swoją wiedzę.

Główny księgowy nie tylko musi kierować się normami prawnymi, ale przede wszystkim powinien przestrzegać określonych norm etycznych. Zgodnie z Kodeksem Etyki Zawodowych Księgowych IFAC [Kodeks etyki... 2009] oraz Kodeksem Zawodowej Etyki w Rachunkowości Stowarzyszenia Księgowych w Polsce [Kodeks zawodowej... 2012] księgowi, wykonując swoją pracę, powinni przestrzegać podstawowych zasad, do których zalicza się uczciwość, obiektywizm, zawodowe kompetencje oraz należytą staranność, zachowanie tajemnicy informacji oraz profesjonalne postępowanie.

Badania dotyczące wizerunku głównego księgowego obejmują także rozpoznanie opinii różnych podmiotów z jego otoczenia na temat wyróżniających go cech osobistych i interpersonalnych. Temu tematowi poświęcono m.in. publikacje A. Juźwickiej, A. Zakrzewskiej-Bielawskiej [2014] i T. Zygmańskiego [2015]. Pierwsze $\mathrm{z}$ opracowań dowiodło, że w opinii przedsiębiorców główną rolę w ocenie głównego księgowego odgrywają wiedza i umiejętności zawodowe. Wśród kompetencji miękkich wyróżniono jedynie skrupulatność, zdolność zachowania poufności oraz lojalność wobec pracodawcy. Podobne ustalenia poczynił T. Zygmański [2015], rozszerzając pożądane cechy osobiste o rzetelność, systematyczność, pracowitość i cierpliwość. 
Ciekawym kierunkiem badawczym są próby ustalenia wizerunku księgowego wśród osób przygotowujących się i rozpoczynających swoją karierę w tym zawodzie. Badania dotyczące tej kwestii prowadzili m.in. U. Drumlak [2013], M. Nowak [2017] i P. Kabalski [2019]. Pierwsza autorka przeprowadziła badania ankietowe wśród studentów i absolwentów kierunku finanse i rachunkowość Uniwersytetu Szczecińskiego. Wyniki ankiety pokazały bardzo pragmatyczne nastawienie respondentów do programów studiów (nasycenie przedmiotami specjalizacyjnymi). Jednocześnie badani okazali się świadomi wysokich wymagań, jakie stawiane są księgowym w zakresie kompetencji miękkich. Badanie M. Nowak [2017] przeprowadzone wśród studentów tego samego kierunku Uniwersytetu Ekonomicznego we Wrocławiu wykazało, że księgowy postrzegany jest jako osoba mądra, o wysokich kompetencjach, o ponadprzeciętnej inteligencji i sprycie, niedająca się wyprowadzić z równowagi oraz pracowita. Wnioski z badania P. Kabalskiego [2019] były bardzo podobne. Przebadani przez wymienionego autora licealiści wskazali ponadto, że pozycja głównego księgowego w przedsiębiorstwie jest średnio znacząca. Jeszcze niżej ankietowani ocenili prestiż społeczny tej profesji.

Niniejsze opracowanie wpisuje się w opisany kierunek badawczy. Jego celem jest poszerzenie ustaleń empirycznych na temat wizerunku głównego księgowego wśród studentów kierunków biznesowych. Badania przeprowadzono wśród studentów Wyższej Szkoły Bankowej, formułując następujące cztery robocze pytania badawcze:

- (P1) Jak postrzegany jest zawód głównego księgowego w zakresie jego pozycji społecznej, rozwoju oraz otoczenia biznesowego?

- (P2) Przez pryzmat jakich cech zawodowych postrzegany jest zawód głównego księgowego?

- (P3) Z jakimi cechami osobistymi kojarzona jest osoba wykonująca zawód księgowego?

- (P4) Jakie cechy interpersonalne charakteryzują głównego księgowego?

\section{Metodyka badania}

Do identyfikacji cech głównego księgowego użyto kwestionariusza ankietowego. Został on podzielony na sześć części. Pierwsza to opis czynności związanych z wykonywaniem zawodu głównego księgowego. Zadaniem respondentów było zaznaczenie tych, które ich zdaniem leżą w kompetencjach głównego księgowego. Spośród ośmiu czynności wskazanych w kwestionariuszu cztery były prawidłowe. Odpowiedzi na tę część ankiety weryfikowały rozpoznawalność wśród ankietowanych zawodu i zadań wykonywanych na tym stanowisku.

Kolejne części ankiety (od drugiej do czwartej) miały identyczną formę i dotyczyły cech zawodowych, osobistych i interpersonalnych głównego księgowego. Przedstawiono je dwubiegunowo, przeciwstawiając sobie cechę negatywną i pozytywną. Respondent przypisywał daną cechę głównemu księgowemu przy użyciu pięciopunktowej skali (1 - zdecydowanie cecha negatywna, 2 - raczej cecha 
negatywna, 3 - obojętnie, 4 - raczej cecha pozytywna, 5 - zdecydowanie cecha pozytywna). Część piątą kwestionariusza stanowiło osiem pytań dotyczących postrzegania zawodu głównego księgowego przez pryzmat jego pozycji społecznej, szans na rozwój oraz relacji z otoczeniem biznesowym. Odpowiedzi można było udzielać również w pięciopunktowej skali ( 1 - zdecydowanie nie, 2 raczej nie, 3 obojętnie, 4 - raczej tak, 5-zdecydowanie tak). Ostatnia część ankiety to metryczka obejmująca informacje o respondencie (stopień i kierunek studiów, doświadczenie w rachunkowości, wiek i płeć).

Analizę uzyskanych ocen liczbowych w ramach części ankiety od drugiej do piątej oparto na podstawowych miarach tendencji centralnej oraz rozproszenia i asymetrii ich rozkładu. Analogiczną metodę gromadzenia i analizy materiału badawczego zastosowali m.in. D. Włodarczyk i B. Tobolska [2011] oraz A. Jakubowicz-Bryx [2016].

W wyniku przeprowadzonej ankiety otrzymano 504 prawidłowo wypełnione kwestionariusze. Strukturę próby badawczej przedstawia tabela 2 .

Tabela 2. Struktura próby badawczej

\begin{tabular}{|c|c|c|c|c|c|}
\hline Kierunek studiów & Liczebność & $\begin{array}{l}\text { Udział } \\
(\mathrm{w} \%)\end{array}$ & Stopień studiów & Liczebność & $\begin{array}{l}\text { Udział } \\
(\mathrm{w} \%)\end{array}$ \\
\hline $\begin{array}{l}\text { Finanse } \\
\text { i rachunkowość }\end{array}$ & 409 & 81,15 & $\begin{array}{l}\text { studia licencjackie } \\
\text { stacjonarne }\end{array}$ & 128 & 25,40 \\
\hline Zarządzanie & 53 & 10,52 & $\begin{array}{l}\text { studia licencjackie } \\
\text { niestacjonarne }\end{array}$ & 205 & 40,67 \\
\hline Prawo w biznesie & 42 & 8,33 & $\begin{array}{l}\text { studia magisterskie } \\
\text { i podyplomowe } \\
\text { (niestacjonarne) }\end{array}$ & 171 & 33,93 \\
\hline $\begin{array}{c}\text { Doświadczenie } \\
\text { w rachunkowości }\end{array}$ & Liczebność & $\begin{array}{l}\text { Udział } \\
(\mathrm{w} \%)\end{array}$ & Wiek & Liczebność & $\begin{array}{l}\text { Udział } \\
(\mathrm{w} \%)\end{array}$ \\
\hline Tak & 243 & 48,21 & \multirow[t]{2}{*}{$19-25$} & \multirow[t]{2}{*}{399} & \multirow[t]{2}{*}{79,17} \\
\hline $\mathrm{Nie}$ & 261 & 51,79 & & & \\
\hline Płeć & Liczebność & $\begin{array}{l}\text { Udział } \\
(\mathrm{w} \%)\end{array}$ & $26-35$ & 63 & 12,50 \\
\hline Mężczyzna & 105 & 20,83 & $36-50$ & 39 & 7,73 \\
\hline Kobieta & 399 & 79,17 & powyżej 50 & 3 & 0,60 \\
\hline
\end{tabular}

Źródło: opracowanie własne.

\section{Wyniki badania}

W analizie materiału badawczego postanowiono wykorzystać tylko te kwestionariusze, których autorzy prawidłowo zidentyfikowali kompetencje głównego księgowego. Za prawidłowe uznano te odpowiedzi, które wskazywały minimum dwie właści- 
we kompetencje. Dla odpowiedzi zawierających trzy i cztery prawidłowe wskazania dopuszczono jedną odpowiedź błędną. Tabela 3 przedstawia udział prawidłowych odpowiedzi w ogólnej liczbie ankiet według wybranych cech respondenta.

Tabela 3. Ankiety z prawidłowo zakreślonymi kompetencjami głównego księgowego (udział liczony w ogólnej liczbie adekwatnych odpowiedzi)

\begin{tabular}{|c|c|c|c|c|c|}
\hline \multicolumn{4}{|c|}{ Pozycja } & Liczebność & Udział \\
\hline \multicolumn{4}{|c|}{ Ankiety z prawidłowo zakreśl. kompetencjami głównego księgowego } & 253 & 50,20 \\
\hline Kierunek studiów & Liczebność & $\begin{array}{l}\text { Udział } \\
(\mathrm{w} \%)\end{array}$ & Stopień studiów & Liczebność & $\begin{array}{l}\text { Udział } \\
(\mathrm{w} \%)\end{array}$ \\
\hline $\begin{array}{l}\text { Finanse } \\
\text { i rachunkowość }\end{array}$ & 208 & 50,86 & $\begin{array}{l}\text { studia licencjackie } \\
\text { stacjonarne }\end{array}$ & 62 & 48,44 \\
\hline Zarządzanie & 19 & 35,85 & $\begin{array}{l}\text { studia licencjackie } \\
\text { niestacjonarne }\end{array}$ & 107 & 52,20 \\
\hline Prawo w biznesie & 26 & 61,90 & $\begin{array}{l}\text { studia magisterskie } \\
\text { i podyplomowe } \\
\text { (niestacjonarne) }\end{array}$ & 84 & 49,12 \\
\hline $\begin{array}{c}\text { Doświadczenie } \\
\text { w rachunkowości }\end{array}$ & Liczebność & $\begin{array}{l}\text { Udział } \\
(\mathrm{w} \%)\end{array}$ & Wiek & Liczebność & $\begin{array}{l}\text { Udział } \\
(\mathrm{w} \%)\end{array}$ \\
\hline Tak & 121 & 49,79 & \multirow[t]{2}{*}{$19-25$} & \multirow[t]{2}{*}{197} & \multirow[t]{2}{*}{49,37} \\
\hline $\mathrm{Nie}$ & 132 & 50,57 & & & \\
\hline Płeć & Liczebność & $\begin{array}{l}\text { Udział } \\
(\mathrm{w} \%)\end{array}$ & $26-35$ & 27 & 42,86 \\
\hline Mężczyzna & 47 & 44,76 & $36-50$ & 26 & 66,67 \\
\hline Kobieta & 206 & 51,62 & powyżej 50 & 3 & 100,00 \\
\hline
\end{tabular}

Źródło: opracowanie własne.

Kompetencje głównego księgowego zidentyfikowała połowa badanych studentów. Wyodrębnione w tabeli 3 cechy respondentów nie różnicują w sposób istotny uzyskanego rozkładu odpowiedzi. Wyjątek stanowi wiek ankietowanych: wraz z jego wzrostem zwiększa się udział odpowiedzi prawidłowych. Zaskakujące jest natomiast to, że wśród osób deklarujących doświadczenie w rachunkowości jedynie połowa potrafiła zidentyfikować kompetencje głównego księgowego.

Biorąc pod uwagę średnią wszystkich ocen $(4,68)$, należy stwierdzić, że respondenci najwyżej ocenili cechy osobiste głównego księgowego. Tabela 4 przedstawia szczegółowe oceny poszczególnych cech, uporządkowane według średniej arytmetycznej. We wszystkich przypadkach zarówno dominanta, jak i mediana wynosiła 5,0.

Bardzo wysoko (średnie powyżej 4,8) respondenci ocenili odpowiedzialność, dokładność i terminowość głównego księgowego. Nieco niżej (średnia 4,75) oceniona została jego uczciwość. Takie cechy, jak samodzielność i wykształcenie, uzyskały relatywnie niższe oceny (średnie 4,58 i 4,55). Najniżej oceniono odporność na 
Tabela 4. Charakterystyka liczbowa cech osobistych głównego księgowego. Wyniki badania

\begin{tabular}{|c|c|c|c|c|c|c|}
\hline \multirow[b]{2}{*}{ Cecha osobista } & \multicolumn{6}{|c|}{ Oceny studentów - podstawowe miary } \\
\hline & $\begin{array}{c}\text { średnia } \\
\text { arytmetyczna }\end{array}$ & dominanta & mediana & $\begin{array}{c}\text { odch. } \\
\text { standardowe }\end{array}$ & $\begin{array}{l}\text { wsp. } \\
\text { zmienności } \\
\text { (w \%) }\end{array}$ & $\begin{array}{c}\text { wsp. } \\
\text { asymetrii }\end{array}$ \\
\hline $\begin{array}{l}\text { Odpowiedzialny } \\
\text { Nieodpowiedzialny }\end{array}$ & 4,8379 & 5,0 & 5,0 & 0,4729 & 9,77 & $-3,6507$ \\
\hline $\begin{array}{l}\text { Dokładny } \\
\text { Niedokładny }\end{array}$ & 4,8340 & 5,0 & 5,0 & 0,5001 & 10,35 & $-3,7559$ \\
\hline $\begin{array}{l}\text { Dochowujący } \\
\text { terminów } \\
\text { Niedochowujący } \\
\text { terminów }\end{array}$ & 4,8261 & 5,0 & 5,0 & 0,4894 & 10,14 & $-3,8631$ \\
\hline $\begin{array}{l}\text { Uczciwy } \\
\text { Nieuczciwy }\end{array}$ & 4,7589 & 5,0 & 5,0 & 0,5430 & 11,41 & $-2,6416$ \\
\hline $\begin{array}{l}\text { Samodzielny } \\
\text { Wymagający } \\
\text { wskazówek }\end{array}$ & 4,5810 & 5,0 & 5,0 & 0,6773 & 14,78 & $-1,9585$ \\
\hline $\begin{array}{l}\text { Wysoko } \\
\text { wykształcony } \\
\text { Nisko } \\
\text { wykształcony }\end{array}$ & 4,5573 & 5,0 & 5,0 & 0,6437 & 14,12 & $-1,6102$ \\
\hline $\begin{array}{l}\text { Odporny na stres } \\
\text { Ulegający stresowi }\end{array}$ & 4,4190 & 5,0 & 5,0 & 0,7601 & 17,20 & $-1,5266$ \\
\hline Razem & 4,6877 & 5,0 & 5,0 & 0,6117 & 13,05 & $-2,3836$ \\
\hline
\end{tabular}

Źródło: opracowanie własne.

stres $(4,42)$. Wskaźniki zmienności wskazują, że im niżej oceniana była cecha, tym odpowiedzi studentów były mniej skoncentrowane wokół średniej. Zakres tego rozproszenia $(9,77-17,20 \%)$ nie jest jednak duży. Wysokie i ujemne wskaźniki asymetrii $(-3,65--1,52)$ oznaczają prawostronny rozkład ocen, czyli studenci najczęściej oceniali dane cechy powyżej średniej arytmetycznej.

Cechy zawodowe głównego księgowego są mniej pozytywnie postrzegane od cech osobistych, jednak ich średnia ocena $(4,40)$ jest także wysoka (patrz tabela 5). Jedynie w odniesieniu do dwóch cech najniżej ocenionych dominanta i mediana to 4,0 .

Cechą ewidentnie odstającą od pozostałych jest doświadczenie w rachunkowości. Średnia arytmetyczna zbliżona do najwyższej oceny i relatywnie niski współczynnik zmienności $(4,88 ; 9 \%)$ świadczą o tym, że respondenci w tym względzie nie mieli wątpliwości i że utożsamiają głównego księgowego z wysokiej klasy specjalistą. Niskie rozproszenie odpowiedzi cechuje także dbałość księgowego o procedury, choć oceniono je nieco niżej $(4,77)$. Cechy, takie jak umiejętność zachowania 
tajemnicy, chęć do podnoszenia kwalifikacji oraz myślenie analityczne, uzyskały noty przeciętne $(4,54-4,66)$. Relatywnie nisko uplasowały się natomiast obiektywizm i wiedza $\mathrm{z}$ zakresu zarządzania. W ocenie respondentów główny księgowy nie odznacza się kreatywnością (średnia 3,64). Wyższa zmienność ocen niż w przypadku cech osobistych wskazuje, że studenci, oceniając cechy zawodowe głównego księgowego, nie byli już tak jednoznaczni. Ujemne wskaźniki asymetrii wskazują jednak, że także częściej oceniali te cechy powyżej średniej arytmetycznej.

Tabela 5. Charakterystyka liczbowa cech zawodowych głównego księgowego. Wyniki badania

\begin{tabular}{|c|c|c|c|c|c|c|}
\hline \multirow[b]{2}{*}{ Cecha zawodowa } & \multicolumn{6}{|c|}{ Oceny studentów - podstawowe miary } \\
\hline & $\begin{array}{c}\text { średnia } \\
\text { arytmetyczna }\end{array}$ & dominanta & mediana & $\begin{array}{c}\text { odch. } \\
\text { standardowe }\end{array}$ & $\begin{array}{l}\text { wsp. } \\
\text { zmienności } \\
(\mathrm{w} \%)\end{array}$ & $\begin{array}{c}\text { wsp. } \\
\text { asymetrii }\end{array}$ \\
\hline $\begin{array}{l}\text { Doświadczenie } \\
\text { w rachunkowości } \\
\text { Brak doświadczenia } \\
\text { w rachunkowości }\end{array}$ & 4,8893 & 5,0 & 5,0 & 0,4405 & 9,01 & $-5,3072$ \\
\hline $\begin{array}{l}\text { Dba o procedury } \\
\text { Nie dba o procedury }\end{array}$ & 4,7708 & 5,0 & 5,0 & 0,5221 & 10,94 & $-2,7454$ \\
\hline $\begin{array}{l}\text { Potrafi zachować } \\
\text { tajemnicę } \\
\text { Nie potrafi zachować } \\
\text { tajemnicy }\end{array}$ & 4,6601 & 5,0 & 5,0 & 0,7093 & 15,22 & $-2,4977$ \\
\hline $\begin{array}{l}\text { Chętnie uzupełnia } \\
\text { wiedzę i zwiększa } \\
\text { umiejętności } \\
\text { Niechętnie uzupełnia } \\
\text { wiedzę i zwiększa } \\
\text { umiejętności }\end{array}$ & 4,5731 & 5,0 & 5,0 & 0,7124 & 15,58 & $-2,0922$ \\
\hline $\begin{array}{l}\text { Myśli analitycznie } \\
\text { Nie myśli analitycznie }\end{array}$ & 4,5494 & 5,0 & 5,0 & 0,6861 & 15,08 & $-1,7397$ \\
\hline $\begin{array}{l}\text { Obiektywny } \\
\text { Subiektywny }\end{array}$ & 4,1383 & 5,0 & 4,0 & 0,9304 & 22,48 & $-0,9048$ \\
\hline $\begin{array}{l}\text { Duża wiedza } \\
\text { z zarządzania } \\
\text { Mała wiedza } \\
\text { z zarządzania }\end{array}$ & 3,9447 & 4,0 & 4,0 & 0,8980 & 22,77 & $-1,0175$ \\
\hline $\begin{array}{l}\text { Kreatywny } \\
\text { Odtwórczy }\end{array}$ & 3,6403 & 4,0 & 4,0 & 1,1448 & 31,45 & $-0,6048$ \\
\hline Razem & 4,3958 & 5,0 & 5,0 & 0,8849 & 20,13 & $-1,6104$ \\
\hline
\end{tabular}

Źródło: opracowanie własne. 
Najmniej pozytywnie wypadła ocena cech interpersonalnych głównego księgowego (patrz tabela 6). Wskazują na to relatywnie niska średnia arytmetyczna $(4,16)$ oraz aż w pięciu na siedem cech wartość dominanty i mediany 4,0 .

Tabela 6. Charakterystyka liczbowa cech interpersonalnych głównego księgowego. Wyniki badania

\begin{tabular}{|c|c|c|c|c|c|c|}
\hline \multirow[b]{2}{*}{ Cecha zawodowa } & \multicolumn{6}{|c|}{ Oceny studentów - podstawowe miary } \\
\hline & $\begin{array}{c}\text { średnia } \\
\text { arytmetyczna }\end{array}$ & dominanta & mediana & $\begin{array}{c}\text { odch. } \\
\text { standardowe }\end{array}$ & $\begin{array}{l}\text { wsp. } \\
\text { zmienności } \\
(\mathrm{w} \%)\end{array}$ & $\begin{array}{c}\text { wsp. } \\
\text { asymetrii }\end{array}$ \\
\hline $\begin{array}{l}\text { Zorganizowany } \\
\text { Niezorganizowany }\end{array}$ & 4,6680 & 5,0 & 5,0 & 0,6240 & 13,37 & $-2,3878$ \\
\hline $\begin{array}{l}\text { Umie kierować } \\
\text { ludźmi } \\
\text { Nie umie kierować } \\
\text { ludźmi }\end{array}$ & 4,2569 & 5,0 & 4,0 & 0,8781 & 20,63 & $-1,4477$ \\
\hline $\begin{array}{l}\text { Chętnie i sprawnie } \\
\text { objaśniający } \\
\text { Niechętnie i źle } \\
\text { objaśniający }\end{array}$ & 4,2134 & 5,0 & 4,0 & 0,8739 & 20,74 & $-1,1847$ \\
\hline $\begin{array}{l}\text { O wysokiej kulturze } \\
\text { osobistej } \\
\text { O niskiej kulturze } \\
\text { osobistej }\end{array}$ & 4,1937 & 4,0 & 4,0 & 0,7651 & 18,24 & $-0,7194$ \\
\hline $\begin{array}{l}\text { Umie pracować } \\
\text { w zespole } \\
\text { Nie umie pracować } \\
\text { w zespole }\end{array}$ & 4,1739 & 4,0 & 4,0 & 0,8737 & 20,93 & $-1,2097$ \\
\hline $\begin{array}{l}\text { Komunikatywny } \\
\text { Niekomunikatywny }\end{array}$ & 4,0909 & 4,0 & 4,0 & 0,8090 & 19,77 & $-0,7115$ \\
\hline $\begin{array}{l}\text { Łatwo nawiązujący } \\
\text { kontakty } \\
\text { Trudno nawiązujący } \\
\text { kontakty }\end{array}$ & 3,9130 & 4,0 & 4,0 & 0,9087 & 23,22 & $-0,7546$ \\
\hline $\begin{array}{l}\text { Życzliwy } \\
\text { Nieżyczliwy }\end{array}$ & 3,7352 & 4,0 & 4,0 & 0,8892 & 23,81 & $-0,2389$ \\
\hline Razem & 4,1556 & 5,0 & 4,0 & 0,8691 & 20,91 & $-0,9800$ \\
\hline
\end{tabular}

Źródło: opracowanie własne.

Wysoko oceniono zorganizowanie głównego księgowego $(4,66)$. Oceny tej cechy były relatywnie zgodne (współczynnik zmienności wynosił 13,37\%). Umiejętność pracy w zespole, kulturę osobistą, chęć i zdolność objaśniania oraz umiejętność kierowania ludźmi oceniono przeciętnie $(4,17-4,26)$. Za najrzadsze cechy księgowego studenci uznali komunikatywność, łatwość nawiązywania kontaktów oraz życz- 
liwość $(3,73-4,09)$. Dla wszystkich cech (oprócz zorganizowania) oceny studentów miały relatywnie duże rozproszenie $(18,24-23,81 \%)$.

Tabela 7. Charakterystyka liczbowa relacyjnego postrzegania zawodu głównego księgowego. Wyniki badania

\begin{tabular}{|c|c|c|c|c|c|c|}
\hline \multirow[b]{2}{*}{ Pytanie } & \multicolumn{6}{|c|}{ Oceny studentów - podstawowe miary } \\
\hline & $\begin{array}{c}\text { średnia } \\
\text { arytmetyczna }\end{array}$ & dominanta & mediana & $\begin{array}{c}\text { odch. } \\
\text { standardowe }\end{array}$ & $\begin{array}{l}\text { wsp. } \\
\text { zmienności } \\
(\mathrm{w} \%)\end{array}$ & $\begin{array}{c}\text { wsp. } \\
\text { asymetrii }\end{array}$ \\
\hline $\begin{array}{l}\text { Pozycja głównego } \\
\text { księgowego wśród } \\
\text { innych zawodów } \\
\text { związanych } \\
\text { z rachunkowością jest } \\
\text { wysoka }\end{array}$ & 4,3241 & 4,0 & 4,0 & 0,6998 & 16,18 & $-1,0342$ \\
\hline $\begin{array}{l}\text { Praca głównego } \\
\text { księgowego } \\
\text { pozytywnie } \\
\text { wpływa na pracę } \\
\text { innych komórek } \\
\text { przedsiębiorstwa }\end{array}$ & 4,1660 & 4,0 & 4,0 & 0,7793 & 18,71 & $-0,7554$ \\
\hline $\begin{array}{l}\text { Główny księgowy to } \\
\text { zawód z przyszłością }\end{array}$ & 4,1023 & 4,0 & 4,0 & 0,9114 & 22,21 & $-0,9658$ \\
\hline $\begin{array}{l}\text { Główny księgowy } \\
\text { wywiera znaczący } \\
\text { wpływ na proces } \\
\text { zarządzania } \\
\text { przedsiębiorstwem }\end{array}$ & 3,9881 & 4,0 & 4,0 & 0,8705 & 21,83 & $-0,5955$ \\
\hline $\begin{array}{l}\text { Pozycja głównego } \\
\text { księgowego } \\
\text { w społeczeństwie jest } \\
\text { wysoka }\end{array}$ & 3,9209 & 4,0 & 4,0 & 0,7623 & 19,44 & $-0,8413$ \\
\hline $\begin{array}{l}\text { Czy chciałabyś/ } \\
\text { chciałbyś zostać } \\
\text { głównym } \\
\text { księgowym? }\end{array}$ & 3,4427 & 4,0 & 4,0 & 1,3008 & 37,79 & $-0,5275$ \\
\hline $\begin{array}{l}\text { Główny księgowy } \\
\text { postrzegany jest jako } \\
\text { partner biznesowy }\end{array}$ & 3,3913 & 4,0 & 4,0 & 1,0432 & 30,76 & $-0,1836$ \\
\hline $\begin{array}{l}\text { Rolą głównego } \\
\text { księgowego jest } \\
\text { edukacja finansowa } \\
\text { innych pracowników }\end{array}$ & 3,3557 & 4,0 & 4,0 & 1,0235 & 30,50 & $-0,2653$ \\
\hline
\end{tabular}

Źródło: opracowanie własne. 
Tabela 7 przedstawia rozkład odpowiedzi z ostatniej części ankiety. Wynika z nich, że studenci zgodzili się z twierdzeniem, że pozycja głównego księgowego wśród zawodów związanych z rachunkowością jest wysoka (średnia 4,32). Nieco niżej ocenili jego pozytywny wpływ na pracę innych komórek organizacyjnych $(4,16)$. Zawód głównego księgowego znalazł też uznanie jako zawód z przyszłością $(4,10)$. Przeciętne oceny charakteryzują natomiast tezy, że główny księgowy wywiera znaczny wpływ na zarządzanie przedsiębiorstwem $(3,98)$ i że ma wysoki status społeczny $(3,92)$. Główny księgowy nie jest postrzegany przez studentów jako partner biznesowy $(3,39)$ i jego rolą nie jest edukacja innych pracowników jednostki $(3,35)$. Relatywnie nisko oceniono także chęć wykonywania tego zawodu $(3,44)$. W przypadku odpowiedzi na tę część ankiety rozproszenie ocen jest zdecydowanie najwyższe (16,18-37,79\%). Podobnie jednak jak we wcześniej omówionych przypadkach częstsze były oceny wyższe niż średnia (ujemne współczynniki asymetrii).

\section{Zakończenie}

Wyniki badania wskazują, że kompetencje głównego księgowego są właściwie rozpoznawane przez połowę respondentów. To stosunkowo wysoki odsetek, biorąc pod uwagę wąską specjalizację tego zawodu. Jego ranga wśród zawodów związanych $\mathrm{z}$ rachunkowością jest wysoka, a praca wykonywana przez osobę na tym stanowisku pozytywnie wpływa na funkcjonowanie innych komórek organizacyjnych. Jest to profesja z przyszłością. Wobec tego nieco zaskakujące jest, że niewiele osób studiujących kierunki biznesowe chciałoby zostać głównym księgowym. Potwierdził się również powszechnie odczuwany fakt, że główny księgowy nie jest postrzegany jako partner w prowadzeniu biznesu. Zatem odpowiedź na pytanie badawcze P1 dotyczące pozycji społecznej zawodu księgowego wyraźnie koresponduje z wynikami badań P. Kabalskiego [2019].

Respondenci najwyżej ocenili cechy osobiste głównego księgowego (odpowiedź na pytanie P3). Jest on postrzegany przez studentów jako osoba odpowiedzialna, dokładna, uczciwa i dochowująca terminów. Nieco mniej pozytywnie oceniane są takie cechy głównego księgowego, jak samodzielność, wykształcenie i odporność na stres.

Nieco niżej oceniono kompetencje zawodowe głównego księgowego (odpowiedź na pytanie P2). W opinii studentów dysponuje on dużym doświadczeniem w rachunkowości, dba o procedury i potrafi zachować tajemnicę. Nieco mniej charakterystycznymi cechami głównego księgowego są w opinii ankietowanych chęć dokształcania i myślenie analityczne. Za rzadsze studenci uznali obiektywizm, wiedzę z zakresu zarządzania i kreatywność.

Najniżej w zagregowanej ocenie studentów uplasowały się cechy interpersonalne głównego księgowego (odpowiedź na pytanie P4). Jest on zdaniem studentów niewątpliwie osobą zorganizowaną. Niżej respondenci ocenili jego umiejętność kierowania ludźmi, umiejętność pracy w zespole, a w konsekwencji komunikatywność. 
Główny księgowy rzadko jest też postrzegany jako osoba życzliwa i łatwo nawiązująca kontakty.

Odpowiedzi na pytania od P2 do P4 nie różnią się znacznie od rezultatów badań innych autorów. Wyraźnie zauważalna jest jedynie odmienna hierarchia oczekiwanych cech głównego księgowego. W innych badaniach dominowały wysokie kompetencje zawodowe, a w badaniu opisywanym $\mathrm{w}$ niniejszym artykule uplasowały się one na drugim miejscu, tuż po cechach osobistych wykonującego ten zawód.

Za główne ograniczenie badania wpływające na interpretację jego wyników należy uznać dwie cechy próby badawczej, to mianowicie, że: 1) badanie objęło studentów jednej uczelni wyższej w Polsce, 2) ankietowanymi byli studenci jedynie kierunków biznesowych.

\section{Literatura}

Brzeska A., 2018, Elementy psychologii stresu w zawodzie księgowego, [w:] Dylematy wspótczesnego przedsiębiorstwa, red. D. Jaczewska, Przedsiębiorczość i Zarządzanie, tom 19, Wydawnictwo Społecznej Akademii Nauk, Łódź-Warszawa.

Czaplińska P., 2015, Strategia budowania wizerunku osób znanych, [w:] Perswazyjne wykorzystanie wizerunku osób znanych, red. A. Grzegorczyk, Wyższa Szkoła Promocji, Mediów i Show Businessu, Warszawa.

Drumlak U., 2013, Badanie opinii na temat przygotowania absolwentów kierunku finanse i rachunkowość do wykonywania zawodu ksiegowego - fragmenty badań, Zeszyty Naukowe Uniwersytetu Szczecińskiego, 765, Finanse, Rynki Finansowe, Ubezpieczenia, 61, s. 5-18.

Jakubowicz-Bryx A., 2016, Wizerunek nauczyciela wczesnej edukacji w opiniach rodziców i nauczycieli, Pedagogika Przedszkolna i Wczesnoszkolna, vol. 4, nr 1(7), s. 7-23.

John J., 2009, Study on the nature of impact of soft skills training programme on the soft skills development of management students, Pacific Business Review, October/December, s. 19-27.

Juźwicka A., Zakrzewska-Bielawska A., 2014, Kompetencje pracowników a outsourcing stużb finansowo-księgowych w małych przedsiębiorstwach, Zeszyty Naukowe Politechniki Łódzkiej, Organizacja i Zarządzanie, 1188(57), s. 27-41.

Kabalski P., 2015, Księgowy jako zawód konwencjonalny - dekonstrukcja stereotypu, Zarządzanie Zasobami Ludzkimi, 1(102), s. 149-164.

Kabalski P., 2019, Postrzeganie księgowych przez polska młodzież licealna-badanie pilotażowe, Zeszyty Teoretyczne Rachunkowości, 102(158), s. 91-110

Klaus P., 2010, Communication breakdown, California Job Journal, 28, s. 1-9.

Krajowy Standard Kompetencji Zawodowych, 2013, Glówny księgowy (121101), Wydawnictwo Naukowe Instytutu Technologii Eksploatacji - PIB, Warszawa.

Kodeks etyki zawodowej IFAC, 2009, https://www.skwp.pl/files/zg/Kodeks_etyki_IFAC.pdf, dostęp: 2.02.2018.

Kodeks zawodowej etyki SKwP, 2012, Stowarzyszenie Księgowych w Polsce, Warszawa.

Low M., Samkin G., Liu Ch., 2013, Accounting education and the provision of soft skills: Implications of the recent NZICA CA academic requirement changes, The E-Journal of Business Education \& Scholarship of Teaching, vol. 7, issue 1, s. 1-33.

Luty Z., 2007, Dylematy zawodu księgowego, [w:] Rachunkowość - wczoraj, dziś, jutro, SKwP, Warszawa. 
Mitchell G.W., Skinner L.B., White B.J., 2010, Essential soft skills for success in the twenty-first century workforce as perceived by business educators, Delta Pi Epsilon Journal, 52, s. 43-53.

Mohamed E., Lashine S., 2003, Accounting knowledge and skills and challenges in a global business environment, Managerial Finance, 29(16).

Nealy C., 2005, Integrating soft skills through active learning in the management classroom, Journal of College Teaching \& Learning, 2(4), s. 1-6.

Nowak M., 2017, Postrzeganie roli wspótczesnego księgowego. Badania z zastosowaniem metafory zoomorficznej, Studia Ekonomiczne. Zeszyty Naukowe Uniwersytetu Ekonomicznego w Katowicach, 341, s. 252-263.

Paszkiewicz A., Silska-Gembka S., 2013, Rola kompetencji miękkich w pracy księgowego - wyniki badań empirycznych, Studia i Prace Kolegium Zarządzania i Finansów, 130, 89-112.

Pluta E., 2001, Public relations - moda czy konieczność? Teoria i praktyka, Twigger, Warszawa.

Ramlall S., Ramlall D., 2014, The value of soft-skills in the accounting profession: Perspectives of current accounting students, Advances in Research, 2 (11), s. 645-654.

Robles M.M., 2012, Executive perceptions of the top 10 soft skills needed in today's workplace, Business Communication Quarterly, 75(4), 453-465.

Rogus M., 2013, Zawód głównego księgowego w jednostkach samorządu terytorialnego, Zeszyty Naukowe Uniwersytetu Szczecińskiego, 786, Finanse, Rynki Finansowe, Ubezpieczenia, 64/2, s. 169-176.

Rozporządzenie Ministra Pracy i Polityki Społecznej z dnia 7 sierpnia 2014 r. w sprawie klasyfikacji zawodów i specjalności na potrzeby rynku pracy oraz zakresu jej stosowania, Dz.U. 2014, poz. 1145.

Smółka P., 2008, Kompetencje społeczne. Metody pomiaru i doskonalenia umiejętności interpersonalnych, Oficyna Wolters Kluwer business, Kraków.

Ustawa z dnia 24 września 1994 r. o rachunkowości, Dz.U. 121/1994, poz. 591 z późniejszymi zmianami.

Ustawa z dnia 27 sierpnia 2009 r. o finansach publicznych, Dz.U. 157/2009, poz. 1240 z późniejszymi zmianami.

Włodarczyk D., Tobolska B., 2011, Wizerunek zawodu pielęgniarki z perspektywy lekarzy, pacjentów i pielegniarek, Medycyna Pracy, nr 62(3), s. 269-279.

Wójcik K., 1997, Public relations od A do Z, Placet, Warszawa.

Zygmański T., 2015, Wymagania pracodawców wobec zawodu księgowego a przygotowanie do zawodu na poziomach ponadgimnazjalnym $i$ wyższym, Folia Pomeranae Univeritatis Technologiae Stetinensis. Oeconomica, 319, (79)2, s. 221-230. 